\title{
PENGARUH UKURAN PERUSAHAAN, LEVERAGE DAN PROFITABILITAS TERHADAP CORPORATE SOCIAL RESPONSIBILITY
}

\author{
Dwi Citra Hardianti ${ }^{1}$ \\ e-mail: dwicitrahardianti57@gmail.com \\ Anwar ${ }^{2}$ \\ e-mail:anwar@stiem-bongaya.ac.id \\ Sekolah Tinggi Ilmu Ekonomi Makassar Bongaya, Indonesia ${ }^{1,2}$ \\ Jalan Letjen. Pol. A, Mappaouddang No. 28, Kota Makassar (0411) 873797
}

\begin{abstract}
Corporate Social Responnsibility is the responsibility of all stakeholders, The problem raised in this study is how the influence of firm size, leverage, profitability on the level of disclosure of corporate social responsibility. This study aims to analyze the influence of these variables, and to contribute in the form of useful information to stakeholders such as investors, owners and management companies in making decisions. This study uses secondary data, while the population used in this study is all companies listed on the Indonesian Stock Exchange with sampling techniques using purposive sampling where sample selection was based on criteria, whereas for research methodology using quantitative qualitative methods with the total number of observations was 27 companies over 2 years of observation, 2017 and 2018. The analysis technique used in this study is multiple linear regression analysis using statistical package for social sciens (SPSS). The results show that firm size variables has influence on corporate social responsibility while leverage and profitability variables have no influnence on corporate social responsibility.
\end{abstract}

Keywords : Firm size, leverage, profitability and corporate social responsibility.

\begin{abstract}
Abstrak
Corporate Social Responsibiity (CSR) merupakan tanggungjawab terhadap seluruh pemangku kepentingan, Adapun permasalahan yang dikemukakan dalam penelitian ini adalah bagaimana pengaruh ukuran perusahaan, leverage dan profitabilitas terhadap corporate social responsibility. Penelitian ini bertujuan untuk menganalisis pengaruh variabel tersebut, dan memberikan kontribusi dalam bentuk informasi yang bermanfaat bagi pemangku kepentingan seperti investor, pemilik dan manajemen perusahaan dalam pengambilan keputusan. Penelitian ini menggunakan data sekunder sedangkan untuk populasi yang digunakan dalam penelitian ini adalah seluruh perusahaan yang terdaftar di Bursa Efek Indonesia dengan teknik pengambilan sampel yaitu menggunakan purposive sampling dimana pemilihan sampel yaitu berdasarkan kriteria, sedangkan untuk metodologi penelitian menggunakan metode kualitatif yang dikuantitatifkan dengan jumlah pengamatan sebanyak 27 perusahaan selama 2 tahun pengamatan yaitu tahun 2017 dan 2018. Adapun teknik analisis yang digunakan dalam penelitian ini adalah analisis regresi linear berganda dengan menggunakan program statistical package for social sciens (SPSS). Hasil penelitian ini menemukan bahwa variabel ukuran perusahaan memiliki pengaruh terhadap corporate social responsibility sedangkan untuk variabel leverage dan profitabilitas tidak berpengaruh terhadap corporate social responsibility.
\end{abstract}

Kata kunci : Ukuran perusahaan, leverage, profitabilitas, corporate social responsibility

\section{PENDAHULUAN}

Dewasa ini akuntansi berkembang pesat, akan tetapi nyatanya pelaporan akuntansi hanya lebih berfokus kepada pertanggungjawaban kepada investor (kaum kapitalis) sehingga hasil output suatu perusahaan juga lebih berpihak kepada investor. Dengan fokus utama perusahaan terhadap investor mengakibatkan beberapa perusahaan lalai akan tanggungjawab sosialnya sehingga melakukan eksploitasi sumber daya alam dan masyarakat secara terus menerus. Dalam hal ini tanggung jawab sosial perusahaan 
merupakan tanggungjawab terhadap seluruh pemangku kepentingan yang diantaranya adalah konsumen, karyawaan, pemegang saham, komunitas dan lingkungan dalam segala aspek operasional perusahaan yang mencakup aspek ekonomi, sosial dan lingkungan.

(Fibrianti, 2015) mengemukakan sejak perusahaan di dirikan maka sejak itulah perusahaan mempunyai beberapa tanggungjawab sosial (Corporate social responsibility/CSR). sesuai dengan konsep Triple Bottom Line (3P) oleh John Elkinton, (1997) menyatakan bahwa perusahaan baik skala besar ataupun kecil yang ingin bertahan dalam jangka waktu lama seharusnya tidak hanya berusaha mengejar profit saja, tetapi berkewajiban untuk berkontribusi terkait dengan aspek sosial masyarakat dan juga lingkungan, konsep 3P ini terdiri dari people, planet dan profit. (Meiyana dan Aisyah, 2019) mengemukakan dengan perusahaan memperhatikan CSR maka citra perusahaan akan semakin baik sehingga loyalitas serta daya tarik konsumen juga akan semakin tinggi. Seiring dengan dilaksanakannya CSR ini juga maka akan meningkatnya loyalitas konsumen sehingga respon konsumen akan semakin positif, dalam hal ini CSR penting dalam upaya membangun citra dan reputasi perusahaan yang pada akhirnya meningkatkan kepercayaann baik dari konsumen maupun mitra bisnis perusahaan.

Tanggungjawab sosial perusahaan atau CSR telah menjadi perhatian dalam beberapa tahun terakhir sebab CSR bukan sekedar kegiatan sukarela melainkan sudah menjadi kewajiban masing-masing perusahaan. Hal ini dikarenakan kegiatan sosial perusahaan telah diatur dalam undang-undang. Adapun beberapa regulasi yang berisi mengenai CSR di Indonesia yaitu Undang-Undang No. 40 Tahun 2007 Pasal 74 menyatakan bahwa "Perseroan yang menjalankan kegiatan usahanya di bidang atau berkaitan dengan Sumber Daya Alam wajib melaksanakan Tanggung Jawab Sosial Dan Lingkungan (TJSL)". Undang-Undang No.25 Tahun 2007 tentang Penanaman Modal, Keputusan Menteri BUMN No. PER-05/MBU/2007 Tahun 2007 tentang Program Kemitraan Bina Lingkungan, Undang-Undang Nomor 32 tahun 2009 tentang Perlindungan dari Pengelolaan Lingkungan Hidup. Dengan diterapkannya regulasi tersebut maka seharusnya perusahaan berkewajiban untuk melaksanakan tanggungjawab serta kepekaan sosialnya terhadap lingkungan (Raditya dkk, 2018).

Peneliti tertarik untuk meneliti CSR karena adanya keresahan dari masyarakat terhadap lingkungan yang kurang mendapat perhatian dimata pemangku kepentingan sedangkan regulasi mengenai CSR sudah jelas diterapkan di Indonesia. Dalam penelitian ini peneliti mengungkapkan ada beberapa faktor yang dapat memengaruhi CSR faktor pertama yaitu ukuran perusahaan, leverage, dan profitabilitas terhadap perusahaan yang terdaftar di Bursa Efek Indonesia. Adapun tujuan penelitian ini adalah untuk mengetahui apakah faktorfaktor tersebut mempunyai pengaruh terhadap corporate social responsibility.

\section{TINJAUAN PUSTAKA}

\section{Ukuran Perusahaan}

Definisi yang dikemukakan oleh (Yuliana dkk, 2019) menyatakan ukuran perusahaan secara umum dapat diartikan sebagai suatu perbandingan besar atau kecilnya suatu objek. Skala perusahaan merupakan ukuran yang dipakai untuk mencerminkan perusahaan yang didasarkan pada total aset perusahaan. Perusahaan yang besar biasanya memiliki modal yang besar pula dan memiliki kemampuan untuk perluasan usaha yang tentunya lebih berani karena modal yang lebih besar dibandikan perusahaan kecil. (Anita, 2015) perusahaan dalam skala besar didukung oleh aset yang besar, sehingga kendala perusahaan yang berhubungan dengan aset dapat diatasi. Total aset disini ditransformasikan kedalam logaritma natural. Rumus dari ukuran perusahaan adalah:

\section{Ukuran Perusahaan $=$ Ln Total Aset}

\section{Leverage}

(Ardian, 2013) menyatakan leverage merupakan alat untuk mengukur seberapa besar perusahaan tergantung kepada kreditur dalam membiayai aset perusahaan. Perusahaan yang mempunyai tingkat leverage tinggi berarti sangat bergantung pada pinjaman luar untuk membiaya asetnya. Sedangkan perusahaan yang mempunyai tingkat leverage rendah berarti lebih banyak membiayai asetnya dengan modal 
sendiri. (Anita, 2015) leverage merupakan nama lain dari rasio utang. Pengukuran leverage dalam penelitian ini dilakukan berdasarkan rasio total hutang terhadap total aset.

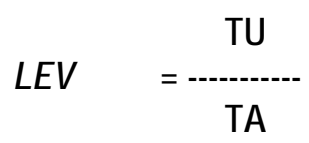

Keterangan:

Lev : Leverage

TU : Total utang

TA : Total aset

\section{Profitabilitas}

Profitabilitas adalah kemampuan perusahaan, lembaga keuangan maupun non lembaga keuangan dalam menghasilkan laba dengan efektif serta efisien dalam suatu periode tertentu (Purnama dan Mayliza, 2018). Profitabilitas yang dihasilkan suatu perusahaan akan mempengaruhi kebijakan investor atas investasi yang dilakukan karena perusahaan yang mempunyai profitabilitas yang tinggi membuat para investor tertarik untuk menanamkan modalnya guna memperluas usaha yang dijalankannya (Heermuningsih, 2012). Rasio profitabilitas adalah tingkat keuntungan yang dapat diperoleh perusahaan dalam kegiatan operasinya. Dalam hal ini Return on equity (ROE) merupakan proksi untuk menghitung profitabilitas perusahaan. ROE diukur dengan menggunakan rumus :

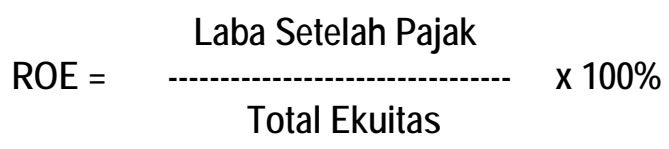

\section{Corporate Social Responsibility}

(Qomariah dkk, 2018) mengungkapkan CSR merupakan bentuk pembangunan keberlanjutan perusahaan dengan bertanggungjawab terhadap sosial, ekonomi, dan lingkungan perusahaan akibat dari aktivitas operasional yang dilakukan perusahaan. Tanggungjawab sosial secara umum adalah dukungan manajemen terhadap kewajiban untuk mempertimbangkan laba, kepuasan pelanggan dan kesejahteraan masyarakat. Hal ini juga diungkapkan oleh (Sholihin dkk, 2018) menyatakan CSR adalah wujud dari kepedulian dan sensitifitas perusahaan untuk ikut meningkatkan kualitas kehidupan masyarakat dan lingkungan serta merupakan bagian dari upaya investasi yang mendukung keberlanjutan dari usaha dikembangkan, tak terpisah dari strategi jangka panjang. Penelitian ini mengacu pada Global Reporting Index (GRI) 4.0 dengan menggunakan 91 indikator pengungkapan CSR (Amalia, 2019). Berikut adalah rumus untuk menghitung besarnya pengungkapan CSR yang dilakukan perusahaan:

$$
\text { Pengungkapan } \quad C S R=\frac{\sum X i}{N}
$$

\section{Keterangan \\ $\sum X i$ : Jumlah indikator CSR yang diungkapkan perusahaan \\ $\mathrm{N} \quad$ : Jumlah indikator menurut GRI 4.0}

\section{METODE PENELITIAN}

Penelitian ini menggunakan data sekunder dengan pendekatan penelitian yakni data kualitatif yang dikuantitatifkan, dengan jenis penelitian desktriptif. Penelitian ini dilakukan pada situs website http://idx.co.id Bursa Efek Indonesia untuk pengambilan data laporan keuangan perusahaan serta menelusuri website perusahaan terkait untuk pengambilan data laporan keberlanjutan perusahaan. Adapun populasi dalam penelitian ini adalah seluruh perusahaan yang terdaftar di Bursa Efek Indonesia dengan teknik pengambilan sampel menggunakan purposive sampling dimana pemilihan sampel yaitu berdasarkan kriteria, dengan 
jumlah pengamatan sebanyak 27 perusahaan selama 2 tahun pengamatan yaitu tahun 2017 dan 2018 dan untuk teknik analisis yang digunakan dalam penelitian ini adalah analisis regresi linear berganda/ multiple regression, analisis ini bertujuan untuk mengetahui hubungan antara variabel dengan menggunakan program statistical package for social sciens (SPSS). Model regresi ini dirumuskan dengan persamaan sebagai berikut

$$
Y=\alpha+\beta_{1} X_{1}+\beta_{2} X_{2}+\beta_{3} X_{3}+e
$$

\section{HASIL DAN PEMBAHASAN}

\section{Hasil Uji Asumsi Klasik}

1. Uji Normalitas

Hasil uji normalitas, dengan analisis statistic uji Kolmogrov-Smirnov (KS) One-Sample KolmogrovSmirnov Test, diketahui bahwa hasil uji nilai Test Statistic sebesar 0,071>0,05 dan nilai Asymo. Sig. (2-tailed) sebesar 0,200c,d $>0,05$ sehingga dapat disimpulkan bahwa data yang diuji berdistribusi secara normal.

2. Uji Multikolinearitas

Hasil uji multikolinearitas diketahui bahwa nilai Tolerance dari ketiga variabel independen lebih besar dari 0,10 . Sementara itu nilai VIF dari ketiga variabel bebas lebih kecil dari 10,00. Sehingga dapat disimpulkan tidak terjadi multikolinearitas.

3. Uji Heterokedastisitas

Hasil uji heterokedastisitas dapat diketahui korelasi antara ketiga variabel independen dengan unstandardized residual menghasilkan nilai signifikansi (Sig 2-tailed) lebih dari 0,05. Karena, nilai signifikansi korelasi lebih dari 0,05 maka dapat disimpulkan bahwa pada model regresi tidak ditentukan adanya masalah heterokedastisitas.

4. Uji Autokorelasi

Hasil uji autokorelasi yaitu yaitu D-W 2,008 > dU 1,7234 dan (4 - D-W) 1,912 > dU 1,7234 dapat disimpulkan bahwa Ho diterima dan Ha ditolak, artinya dalam penelitian ini tidak terdapat autokorelasi antara periode $t$ dengan periode sebelumnya.

\section{Analisis Data Penelitian}

\section{Analisis Statistik Deskriptif}

Tabel 1

Hasil Analisis Statistik Deskriptif

Descriptive Statistics

\begin{tabular}{|l|r|r|r|r|r|r|r|}
\hline & \multicolumn{1}{|c|}{ N } & Minimum & Maximum & \multicolumn{1}{c|}{ Sum } & Mean & Std. Deviation & Variance \\
\hline CSR & 54 & 5.00 & 67.00 & 1378.00 & 25.5185 & 13.71370 & 188.066 \\
ROE & 54 & -18.00 & 517.00 & 1436.00 & 26.5926 & 72.83751 & 5305.303 \\
LV & 54 & -4596.00 & 1106.00 & 12534.00 & 232.1111 & 755.41431 & 570650.780 \\
UP & 54 & 2880.00 & 3480.00 & 172238.00 & 3189.5926 & 154.34677 & 23822.925 \\
Valid N (listwise) & 54 & & & & & & \\
\hline
\end{tabular}

Data diolah, 2019

Hasil statistik deskriptif sampel penelitian menunjukkan jumlah sampel yang digunakan dalam penelitian ini, nilai minimum, nilai maksimum, nilai sum, nilai mean, nilai standar deviasi dan nilai varians terhadap masingmasing variabel. Hasil statistik deskriptif dapat dilihat pada tabel 1. 


\section{Uji Hipotesis Dengan Analisis Regresi Linear Berganda}

Uji hipotesis dilakukan dengan menggunakan regresi linear berganda, untuk menguji kelayakan model persamaan regresi dan untuk mengetahui apakah secara parsial variabel independen berpengaruh secara signifikan terhadap variabel dependen.

\section{Hasil Uji Simultan (Uji F)}

Tabel 2

Hasil Uji Simultan

ANOVA $^{\mathrm{a}}$

\begin{tabular}{|ll|r|r|r|r|r|}
\hline Model & & Sum of Squares & df & Mean Square & F & \multicolumn{1}{|c|}{ Sig. } \\
\hline 1 & Regression & 3294.019 & 3 & 1098.006 & 8.227 & $.000^{\circ}$ \\
& Residual & 6673.463 & 50 & 133.469 & & \\
& Total & 9967.481 & 53 & & & \\
& & & & & \\
\end{tabular}

a. Dependent Variable: CSR

b. Predictors: (Constant), ROE, UK, LV

Data diolah, 2019

Hasil uji simultan pada $F_{\text {hit }} 8,227$ lebih besar dibanding $F_{\text {tab }} 2,790$ dan besarnya probabilitas value $=$ 0,000 lebih kecil dari $5 \%(a=0,05)$ maka Ha diterima dan Ho ditolak. Artinya dengan tingkat kepercayaaan 95\% dapat dikatakan bahwa Ukuran Perusahaan, Laverage, Profitabilitas secara simultan berpengaruh terhadap Corporate Social Responsibility.

\section{Hasil Uji Parsial (Uji T)}

Tabel 3

Hasil Uji Parsial

Coefficients $^{\mathrm{a}}$

\begin{tabular}{|c|c|c|c|c|c|}
\hline \multirow[b]{2}{*}{ Model } & \multicolumn{2}{|c|}{$\begin{array}{l}\text { Unstandardized } \\
\text { Coefficients }\end{array}$} & \multirow{2}{*}{$\begin{array}{l}\text { Standardized } \\
\text { Coefficients } \\
\text { Beta }\end{array}$} & \multirow[b]{2}{*}{$t$} & \multirow[b]{2}{*}{ Sig. } \\
\hline & B & Std. Error & & & \\
\hline (Constant) & 173.321 & 35.889 & & 4.829 & .000 \\
\hline UK & -.046 & .011 & -.522 & -4.048 & .000 \\
\hline LV & -.001 & .005 & -.055 & -.208 & .836 \\
\hline ROE & .016 & .047 & .086 & .344 & .732 \\
\hline
\end{tabular}

a. Dependent Variable: CSR

Data diolah, 2019

Hasil uji Ukuran perusahaan berpengaruh terhadap Corporate Social Responsibity karena nilai signifikannya lebih kecil dari 0,05. Dan untuk leverage dan profitabilitas tidak berpengaruh terhadap Corporate Social Responsibility karena nilai signifikannya lebih besar dari 0,05.

\section{Hasil Uji Determinasi (R2)}


Tabel 4

Hasil Uji Determinasi

Model Summary

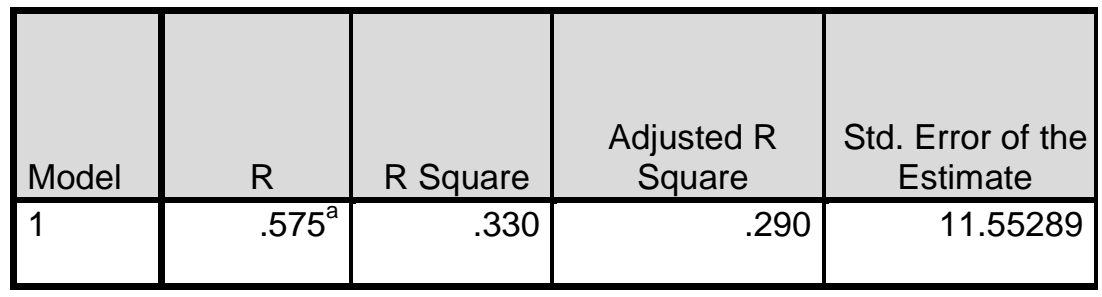

a. Predictors: (Constant), ROE, UK, LV

Data diolah, 2019

Hasil output uji determinasi yaitu 0,330 yang berarti apabila dikalikan seratus persen maka kemampuan variabel-variabel independennya menjelaskan variabel dependennya sebesar 33\%.

\section{PEMBAHASAN}

\section{Pengaruh Ukuran perusahaan terhadap Corporate Social Responsibility}

Hasil Uji Regresi Linear Berganda menunjukkan $t$ hit -4.048 lebih besar dibanding $t$ tab 2,006 dan besarnya probabilitas value $=0,000$ lebih kecil dari $5 \%(a=0,05)$ maka Ha diterima dan Ho ditolak. Artinya dengan tingkat kepercayaaan 95\% dapat dikatakan bahwa Ukuran Perusahaan berpengaruh terhadap corporate social responsibility (CSR) pada perusahaan yang terdaftar di Bursa Efek Indonesia. Dalam hal ini Artinya bahwa perusahaan besar yang dinilai dengan tingkat aktiva yang besar akan mengungkapkan lebih banyak tanggung jawab sosialnya terhadap perusahaan, hal ini juga demi menjaga kepercayaan konsumen dan investor termasuk dalam menjaga persentase laba perusahaan Hasil penelitian ini sejalan dengan penelitian yang dilakukan oleh (Sholihin, 2018).

\section{Pengaruh Leverage terhadap Corporate Social Responsibility}

Hasil Uji Regresi Linear Berganda menunjukkan $t$ hit $-0,208$ lebih kecil dibanding $t$ tab 2,006 dan besarnya probabilitas value $=0,836$ lebih besar dari $5 \%(a=0,05)$ maka Ha ditolak dan Ho diterima . Artinya dengan tingkat kepercayaaan 95\% dapat dikatakan bahwa Laverage tidak berpengaruh terhadap corporate social responsibility (CSR) pada perusahaan yang terdaftar di Bursa Efek Indonesia. Hal ini dapat diartikan bahwa besar kecilnya rasio leverage suatu perusahaan tidak mempengaruhi luas pengungkapan CSR yang dilakukan perusahaan. Hal ini dikarenakan sudah terjadi hubungan yang baik antara perusahaan dengan debtholders, yang mengakibatkan debtholders tidak terlalu memperhatikan rasio leverege perusahaan. Dari hasil penelitian ini dapat juga dikatakan bahwa CSR disclosure lebih bergantung pada total aset perusahaan secara keseluruhan yang digunakan untuk membiayainya, tanpa melihat seberapa besar aset yang diperoleh dari hutang kepada kreditor. Hal ini didukung oleh penelitian (Nurjanah, 2015).

\section{Pengaruh Profitabilitas terhadap Corporate Social Responsibility}

Hasil Uji Regresi Linear Berganda menunjukkan $t$ hit 0,344 lebih kecil dibanding $t$ tab 2,006 dan besarnya probabilitas value $=0,732$ lebih besar dari $5 \%(a=0,05)$ maka Ha ditolak dan Ho diterima . Artinya dengan tingkat kepercayaaan 95\% dapat dikatakan bahwa Profitabilitas tidak berpengaruh terhadap corporate social responsibility (CSR) pada perusahaan yang terdaftar di Bursa Efek Indonesia. Penyebabnya adalah ketika perusahaan memiliki tingkat laba yang tinggi, perusahaan menganggap tidak perlu melaporkan hal-hal yang dapat mengganggu informasi tentang kesuksesan keuangan perusahaan Dan perusahaan hanya fokus untuk memiliki citra yang baik dan kinerja keungan yang baik pula, sehingga investorpun akan tertarik untuk berinvestasi. Sebaliknya, pada saat tingkat profitabilitas rendah, mereka berharap para pengguna laporan akan membaca "good news" tentang kinerja perusahaan. Hal ini sejalan dengan penelitian yang dilakukan oleh (Wijaya, 2012). 


\section{KESIMPULAN}

Berdasarkan pengujian terhadap tiga hipotesis yang dilakukan dengan menggunakan metode regresi linear berganda. maka dapat ditarik kesimpulan sebagai berikut : ukuran perusahaan mempunyai pengaruh terhadap Corporate Social Responsibility dengan artian semakin besar total aset maka semakin besar pula ukuran perusahaan. ini menadakan semakin besar ukuran perusahaan maka semakin tinggi pula pengungakapan tanggungjawab sosialnya. Lain halnya dengan Leverage dan profitabilitas yang tidak mempunyai pengaruh terhadap Corporate Social Responsibility. Untuk leverage besar kecilnya rasio leverage suatu perusahaan tidak mempengaruhi luas pengungkapan CSR yang dilakukan perusahaan karena sudah terjadi hubungan yang baik antara perusahaan dengan debtholders, yang mengakibatkan debtholders tidak terlalu memperhatikan rasio leverege perusahaan. Dan untuk profitabilitas ketika perusahaan memiliki tingkat laba yang tinggi, perusahaan menganggap tidak perlu melaporkan hal-hal yang dapat mengganggu informasi tentang kesuksesan keuangan perusahaan seperti pertanggungjawaban sosial.

Adapun saran yang dapat penulis berikan sehubungan dengan penelitian ini, bagi peneliti selanjutnya untuk menambah variabel serta tahun pengamatan yang lebih panjang, sehingga dengan demikian hasil penelitian diharapkan dapat mewakili kondisi perusahaan-perusahaan yang ada secara keseluruhan.

\section{DAFTAR PUSTAKA}

Amalia, Firda Ayu. (2019). Pengungkapan Corporate Social Responsibility (CSR) Dan Penghindaran Pajak: Kepemilikan Konstitusional Sebagai Variabel Moderasi.Jurnal Akuntansi dan Ekonomi FE. UNPGRI.4 (2): 14-23.

Anita, F., Basri, Y. M., \& Julita, J. (2015). Pengaruh Corporate Social Responsibility, Leverage, Likuiditas, Dan Ukuran Perusahaan Terhadap Agresivitas Pajak (Studi Empiris Pada Perusahaan Real Estate Dan Property Yang Terdaftar Di Bursa Efek Indonesia Tahun 2010-2013). Jurnal Online Mahasiswa Fakultas Ekonomi Universitas Riau, 2(2).

Ardian, H., \& RAHARJA, S. (2013). Faktor-Faktor Yang Mempengaruhi Kebijakan Pengungkapan Tanggung Jawab Sosial Dan Lingkungan (Studi Empiris Pada Seluruh Perusahaan Yang Terdaftar Di Bursa Efek Indonesia Tahun 2010) (Doctoral dissertation, Fakultas Ekonomika dan Bisnis).Dengan Sruktur Modal Sebagai Variabel Intervening. Jurnal Siasat Bisnis, 16.I

Fibrianti, N. P. E. (2015). Pengaruh Hutang, Profitabilitas, dan Tanggung Jawab Lingkungan pada CSR Disclosure Perusahaan Pertambangan. E-Jurnal Akuntansi, 99-114.

Hermuningsih, S. (2012). Pengaruh profitabilitas, Size Terhadap Nilai Perusahaan

Meiyana, A., \& Aisyah, M. N. (2019). Pengaruh kinerja lingkungan, biaya lingkungan, dan ukuran perusahaan terhadap kinerja keuangan dengan corporate social responsibility sebagai variabel intervening. Nominal, Barometer Riset Akuntansi dan Manajemen, 8(1). Mikroskil, 3(April), 51-60.

Nilai Perusahaan Pada Perusahaan Farmasi Jurnal Wira Ekonomi Nurjanah, N. (2015). Kinerja Lingkungan, Leverage, Profil dan Pertumbuhan Perusahaan; Pengaruhnya terhadap CSR Disclosure (Doctoral dissertation, Universitas Negeri Semarang).

Purnama, S., \& Mayliza, R. (2019). Nilai Perusahaan Di Lihat Dari Aspek Profitabilitas, Ukuran Perusahaan Dengan Struktur Modal Sebagai Variabel Intervening. INA-Rxiv. July, 31.

RADITYA, K. I., Purnamawati, I. G. A., \& Prayudi, M. A. (2018). Analisis Perlakuan Akuntansi Dan Pelaporan Pertanggujawaban Sosial Pada Perusahaan (Studi Kasus pada PT. PLN (Persero) Distribusi Bali Area Bali Utara, Kota Singaraja). JIMAT (Jurnal IImiah Mahasiswa Akuntansi) Undiksha, 8(2).

Qomariah, N., Martini, N. N. P., \& Paramu, H. (2018). Dampak tata kelola perusahaan, tanggung jawab sosial perusahan dan intelectual capital terhadap profitabilitas perusahaan. Jurnal Sains Manajemen dan Bisnis Indonesia, 8(1). 
Sholihin, M. R., \& Aulia, Y. (2018). Analisis faktor-faktor yang mempengaruhi pengungkapan corporate social responsibility (studi empiris perusahaan manufaktur yang terdaftar di bursa efek Indonesia). Jurnal Analisa Akuntansi dan Perpajakan, 2(2).

Wijaya, M. (2012). Faktor-faktor yang mempengaruhi pengungkapan tanggung jawab sosial pada perusahaan manufaktur yang terdaftar di Bursa Efek Indonesia. Jurnal IImiah Mahasiswa Akuntansi, 1(1), 26-30.

Yuliana, Y., Chudri, I. R., \& Umar, Z. (2019). Pengaruh Solvabilitas dan Ukuran Perusahaan terhadap Nilai Perusahaan pada Perusahaan Restaurant, Hotel \& Tourism Yang terdaftar di Bursa Efek Indonesia Tahun 2015-2017. Jurnal IIman: Jurnal IImu Manajemen, 7(1). 